\title{
Ethics, Knowledge, and Rule-Following
}

A Pragmatist View

\section{Andreas Hetzel}

Translator. Julia Schleinkofer

\section{(2) OpenEdition}

\section{Journals}

Electronic version

URL: http://journals.openedition.org/ejpap/376

DOI: 10.4000/ejpap.376

ISSN: 2036-4091

\section{Publisher}

Associazione Pragma

\section{Electronic reference}

Andreas Hetzel, «Ethics, Knowledge, and Rule-Following », European Journal of Pragmatism and American Philosophy [Online], VII-1 | 2015, Online since 07 July 2015, connection on 10 December 2020. URL : http://journals.openedition.org/ejpap/376 ; DOI : https://doi.org/10.4000/ejpap.376

This text was automatically generated on 10 December 2020.

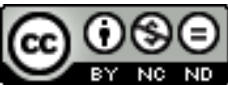

Author retains copyright and grants the European Journal of Pragmatism and American Philosophy right of first publication with the work simultaneously licensed under a Creative Commons Attribution-

NonCommercial-NoDerivatives 4.0 International License. 


\title{
Ethics, Knowledge, and Rule- Following
}

\author{
A Pragmatist View
}

\section{Andreas Hetzel}

Translation : Julia Schleinkofer

\section{Introduction}

2 In linguistics verbs that indicate the necessary beginning of an action are called inchoative verbs, based on the Latin term inchoãre - 'to begin.' They differ from durative and resultative verbs that refer to the course and the result of an action respectively. In German 'brennen' - ('to burn'), for example, is the durative counterpart of the resultative 'verbrennen' ('to burn up or combust'), and the inchoative 'entbrennen' ('to burst into flames'). Based upon pragmatist positions, in this paper I would like to describe the originality and peculiarity of the ethical as an enabling of beginnings. In doing so, a perspective is established whereby ethical demands can neither be attributed to propositional and proposition-based knowledge nor represented by a norm, as all knowledge and all norms confirm existing orders, define someone or something as being such-and-such, and therefore have a tendency to inhibit new beginnings.

3 I consciously refer to the 'originality' rather than the 'autonomy' of ethical claims in order to emphasize the point that, while moral demands cannot be ascribed to God or nature, they also cannot be based upon human positing alone, as claimed by conctractualism: they have no foundation in a pre-existing entity such as God or nature, but they are still given in a fundamental sense, given in and with human practice. On the one hand, practice is nothing other than what we make it, but on the other hand, we cannot ever desist from or abandon practice, which makes it impossible to turn it entirely into an object of theoretical contemplation. 
4 Aristotle once defined human practice as the activity of being with others through words and deeds whose value is intrinsic. He describes practice as open and contingent. It is characterized by the fact that in practice things could always be different or be started over afresh. However, he limits practice to the polis as a stage for the encounter of free and equal citizens and thus distinguishes it from other types of actions such as labour or fabrication (poiesis) on the one hand, and the biological process of life in general on the other.

5 In contrast to this approach, ever since Marx, we tend to conflate practice with life and labour, and at the same time conceive it as something that is structured by underlying patterns and norms: as an expression of the reproduction of objective conditions of its possibility. Practice here inherits a necessity or causality that it in turn impresses itself upon thinking. In order to suppress the creative and experimental spontaneity of practice Marx himself exposed, orthodox Marxism accentuates a certain heaviness and irreducibility of practice that Aristotle limits to other types of activities as well as to the biological process of life. For Aristotle, this spontaneity makes practice to the privileged place for the emergence of new beginnings. On the other hand it could be said that, according to orthodox Marxism, the subject is always overpowered by a practice which makes it impossible to start something new.

6 Meanwhile, pragmatism succeeds in combining both heaviness and lightness of practice which is characterized as irreducible and indeterminate at the same time. Various kinds of pragmatist ethics criticize the assumption of objective structures that supposedly determine practice and try to eliminate its spontaneity. The normative measure for this kind of criticism in turn can be nothing other than the inchoative openness of life practice itself, the formula used by Peirce and Dewey that we should "not block the road to inquiry" (Peirce 1931: 135). The advantage of this normative measure is that it is conceptualized as entirely intra-mundane or naturalistic, but at the same time it does not encourage ethical relativism.

7 In doing so, pragmatism sets itself apart not only from objectivistic approaches in social philosophy, but also from deontological ethics in the tradition of Kant. According to deontological approaches, practical reason is a representation of formal, as well as transcendental, principles that serve as external measures for criticizing practical actions. Deontological principle ethics thus tend to dictate particular forms of practice and conform to their respective normative standards. It leaves no room for ruptures or responsible decisions, therefore does not know any true beginnings. ${ }^{1}$ By contrast, an inchoative or pragmatist ethics would consider a practice as ethically justified only if it resists the temptation to be subordinated under one single rule and the knowledge which is embodied in this rule.

8 In the first section of my paper, I will try to show that the originality of the ethical already for Plato and Kant cannot be represented as either propositional knowledge or a norm, but is instead given to us in a way that is never fully in our rational grasp (1). In the second section, I will address the ethical conclusions James and Dewey draw from the fact that ethical demands cannot be translated into forms of knowledge (2). In the third section, I conclude by arguing the originality of the ethical based upon the work of Stanley Cavell, stating that it is always something more than mere competence in the sense of a knowledge of rules (3). 


\section{Ethical Demands and Limits of Knowledge: From Plato to Kant}

9 At first glance, it may seem trivial to point out that the possibility of acting morally is sub-ject to complex epistemic conditions. In order to act morally, we require knowledge regarding, for example, the coordinates of the situation we are about to participate in, the potential consequences of our action, the conflicting claims of other actors, the normative measures that may provide orientation to our actions, as well as the procedures that can ideally justify these measures. There is no denying that knowledge is relevant for moral action. Nevertheless, from a pragmatic perspective the question remains as to whether knowledge is a sufficient and appropriate condition for virtue, if, in other words, the originality of the ethical is explicable as a form of propositional knowledge.

10 Currently, on the level of justification as well as the application of ethics, a rationalist prejudice prevails that correct and well-founded knowledge will automatically lead to what is right, in other words: moral and practical validity claims depend upon epistemic validity claims. This ethical intellectualism has a prominent historical predecessor, Socrates, whose position Bruno Snell recapitulates as follows:

I think it is possible to indicate the origin of Socrates' discussion of morals: The Medea of Euripides says: "I know what evil I am about to do, but my passion is stronger." Socrates counters: "If only one knows what is good, one will also do good - it is merely a question of genuinely realizing what is good. Nobody is voluntarily doing evil." (Snell 1955: 248)

11 Socrates at first glance seems to be an ethical intellectualist. According to him, we should strive for eudaimonia, a 'good life' that, as soon as we know what it is, we will want to live it. Above all, this 'good life' would be the life of a man guided by his pursuit of knowledge. Apology 28a further explains that well-founded knowledge is achieved by constantly "questioning one self and others," that is, questioning the possible justification for different opinions. Socrates is well aware that theoretical knowledge alone cannot provide a sufficient and appropriate motivation for our ethical actions: Knowledge has to be complemented by virtue or by a person's character, their areté, which is characterized as the ability to do well. But, according to Socrates, this areté in turn depends upon a knowledge that acts as a condition of its possibility. In Laches (199d) and Charmides (174c), Socrates talks about "knowledge of good and evil" as a condition for areté (compare Hardy 2010). Ignorance is explicitly considered to be the greatest $\sin$.

12 Is Socrates, therefore, an ethical intellectualist (as, for example, claimed by Hardy 2010: 149-191)? Doubts are in order here, mainly deriving from what knowledge of the good could actually mean from Plato's perspective. In Philebos Plato transfers the good into a sphere "beyond being and essence" and, herein following Anaximander, characterizes it as ápeiron, infinite and indeterminate (compare Philebos 28a). It is not part of the sphere of logon didonei and thus calls for another capacity - nous - which does not aim at propositional knowledge, but a pre-reflective one that cannot be justified, but is at best presupposed and plays an irritating, rather than a guiding, role in all our relations with the world.

13 This scepticism as to whether the good is a form of knowledge is already hinted at in the early dialogue Meno. In this dialogue, Socrates doubts the ability to teach virtue with the 
argument that virtue is of a completely different kind than propositional knowledge and represents a realm that has a validity of its own. Plato is the origin of two different traditions: a) an intellectualist tradition stating that when it comes to our ethical actions we are orientated by a model, a theoretical ideal form (eidos) which we realize as a telos in our ethical actions, and b) a tradition emphasizing the irreducible originality of the ethical that precedes any knowledge and positively suspends existing regimes of knowledge.

Analogous to John L. Austin's notion of descriptive fallacy in the language philosophy of logical positivism, I would like to characterize the rationalist assumption that on the one hand it is possible to achieve knowledge which is relevant to action in any given situation, and that on the other this knowledge provides us with immediate ethical motivation is an intellectual fallacy: the meaning of ethical claims cannot be reduced to a propositional and proposition-based knowledge. This does not answer the question as to whether the ethical could be based on a different, non-propositional kind of knowledge, for example, a genuinely practical knowledge as outlined in the Aristotelian notion of phronesis. But at this point I will not pursue that question any further, as any definition of practical knowledge already has to include a certain knowledge of the practical, the possibility of which is precisely what is up for debate here.

Like Plato's philosophy, Kant's philosophy also seems to oppose a simple ethical rationalism or intellectualism. Contrary to what is often assumed, the highest point of Kant's moral philosophy is not knowledge of the law (or rather the very form of the law), but the sentiment of 'respect' ('Achtung') that we not only owe the law, but the other person too. This sentiment, which Kant refers to with "you ought," is not identical with the law, but is at best reflected in it. For Derrida, it is the paradox of Kantian ethics that the sentiment of respect

[...] inscribes in the heart of a morality incapable of giving an account of being inscribed in an affect or in a sensibility of what should not be inscribed there or should only enjoin the sacrifice of everything that would only obey this sensible inclination. (Derrida 1995b: 31)

More than anything else, Kant's repeated hint at the "fact of reason" (cf. Kant 2002b: 46), something that is given and underlies all morality, is a clue that the originality of ethics amounts to something more than simply the formal shape of the law of morality. Kant's remark that morality can be neither "searched for" nor "invented" (cf. Kant 2002b: 133), but only presupposed goes in this same direction. To explain Kant in Ernesto Laclau's words: "There is an ethical investment in particular normative orders, but no normative order which is, in and for itself, ethical" (Laclau 2000: 81). The ethical can never be identical to any normative order, because all norms are made by man, remain contingent, and are not able to cover all aspects of the ethical. So the ethical is a empty signifier: "It is, to use Kant's term, a noumenon, an object which shows itself through the impossibility of its adequate representation" (Laclau 2002: 3). Contrary to the normative order, the ethical is

[...] related to the experience of the unconditional in an entirely conditioned universe. And this experience of the unconditional is the kernel of any notion of ethics. (Laclau 2002: 3)

17 In my opinion, Kant, like Plato, alternates between ethical intellectualism and antiintellectualism. He remains intellectualist in his assumption that we are able to know the foundation of ethical actions - the law of morality - without any mediation: "But if I think of a categorical imperative, then I know [since I myself am the author of this imperative] 
directly what it contains" (Kant 2002a: 37). Here the motive of doing well (the good intention) weighs more than the consequences of an action. Kant states that man remains "inexperienced in regard to the course of the world, incapable of being prepared for all the occurrences that might eventuate in it" (Kant 2002a: 19), which is why ethics cannot be justified from a solely consequentialist perspective. But at the same time, Kant underlines that, on the level of intention, something runs counter to knowledge:

In fact even through the most strenuous testing, we can never fully get behind the covert incentives, because when we are talking about moral worth, it does not depend on the actions, which one sees, but on the inner principles, which one does not see. (Kant 2002a: 23)

Such an incitement for Kant is most notably freedom, which in turn is nothing other than the capacity to begin. In reference to this central principle of practical reason, he remarks that it is the only idea "whose possibility we know a priori - though without having insight into it" (Kant 2002b: 5). Only as an expression of freedom can the law of morality be considered as "absolutely great" (a phrase which Kant constantly uses to allude to the Platonic apeiron). I can never know of freedom as freedom, as any knowledge already requires freedom. Seeing that, Kant towards the end of his Groundwork comes up with an outright negativist resumé of his ethics:

And thus we indeed do not comprehend the practical unconditioned necessity of the moral imperative, but we do comprehend its incomprehensibility. (Kant 2002a:

79)

If I had to conceptually place the position only hinted at in this brief comments on Plato and Kant in the current meta-ethical debate (see Horster 2012), I would say that I share the premise of ethical realists such as McDowell, Nagel, or Putnam that moral facts, for instance claims and demands, have an autonomous existence regardless of us. I disagree with them, however, insofar as I do not consider moral sentences to be truth-apt. Rather, they raise a different kind of validity claim which is why the task of moral philosophy is not the adequate representation of moral facts. I agree with a certain non-cognitivism in non- or anti-realistic positions as represented, for example, by Ayer, Stevenson, Mackie, Hare, or Blackburn. Moral judgements are not representations of moral facts; but I part with anti-realism in thinking that they certainly do depend upon independent facts (claims, an 'ought to').

To me, the pragmatist notion of practice seems to mark the corresponding position between ethical realism and anti-realism: Moral facts exist regardless of us in that they are part of a practice that is given and cannot be abandoned by simply reflecting our way out of it. At the same time, those facts do not have a status that allows us to know them or represent them in any way. However, this does not mean that they amount to nothing more than simple preferences, as claimed by many of the non-realists.

\section{Ethics as Practice: From James to Dewey}

In case an intellectualist tradition of ethics should succeed in deducing practical validity claims from theoretical validity claims, the question of justifying ethical judgements would appear to be a special case of the question of justified theoretical convictions. Conversely, this would imply that insufficiently founded knowledge claims are also problematic with respect to ethics. William Clifford confronted early American Pragmatism with precisely this criticism in his 1885 essay Ethics of Belief. Against this 
backdrop, William James' answer, The Will to Belief (1897), can be read as an attempt to rescue the originality of the ethical. With The Will to Belief, James works towards two different aims. On the one hand, he pursues a "justification of faith" (James 1956: 1), of belief in the sense of a hypothesis in the realm of the life-world, while on the other he seeks to show that certain practical contexts allow a "justification by faith" (James 1956: 1), that is through convictions that are not entirely justifiable. James strives for the rehabilitation of belief and in this context highlights the fact that human practice is only able to be rationalized to a certain degree. He points out that we always already hold beliefs in our everyday life, such as "in molecules and the conservation of energy, in democracy and necessary progress, in Protestant Christianity" (James 1956: 9) and so on without being able to state "reasons worthy of the name" (James 1956: 9).

James can here refer to Aristotle, who describes practice as a realm of irreducible contingency where things could always just as well be completely different. Ethics and politics as sciences of practice exclusively refer to "subjects" which

[...] seem to present us with alternative possibilities: about things that could not have been, and cannot now or in the future be, other than they are, nobody who takes them to be of this nature wastes his time in deliberation. (Arist. Rhet. 1357a)

This conclusion, which is hard to accept for rationalists and scientists, does not lead James into an abstinence from judging altogether as is typical of radical scepticism, or even into irrationalism. Understanding that there are no ultimate reasons behind practice in fact compels pragmatism to attempt a justification of practice through the absence of ultimate foundations or through its performativity. Paraphrasing James, it could be said that practice involves an uncovered faith in an option that will only be justifiable in retrospect:

There are, then, cases where a fact cannot come at all unless a preliminary faith exits in its coming. And where faith in a fact can help create the fact, that would be an insane logic which should say that faith running ahead of scientific evidence is the 'lowest kind of immorality' into which a thinking being can fall. Yet such is the logic by which our scientific absolutists pretend to regulate our lives! (James 1956: 25)

While Clifford insinuates an ethics that seeks to anchor convictions in well-founded knowledge, James elaborates a certain inevitability of unfounded convictions. For Clifford, only a conviction that is scientifically founded, or at least founded in a way analogous to science, could count as justified. He illustrates the assumed moral consequences of pragmatism with the example of a ship owner that allows a ship full of emigrants to sail even though he is aware that it is old and ramshackle and therefore is in danger of capsizing. The example implies that the ship owner holds a diffuse belief that things will go well, just as they have done many times before. Clifford uses this diffuse belief as a paradigm for poorly founded convictions, 'doxa' in contrast to 'episteme,' and thus critiques James' belief. But is his example not, first of all, an example of something else entirely? Namely, that in spite of having well-founded knowledge of something, we still do not act according to this knowledge? Which makes it rather an example that refutes the intellectualist assumption of rationalist ethics that well-founded knowledge automatically leads into doing what is right.

In contrast, James brings into play a completely different dimension. A conviction becomes a living option only if I can accept responsibility for its consequences, regardless of how well or poorly founded it is. But I can only meaningfully accept responsibility for something the consequences of which are not yet certain. In the same manner, it is one of 
the conditions of making a promise that I can only meaningfully promise what would not have happened in the course of events anyway. For James, the impossibility of basing practice entirely upon knowledge is the condition of possibility of accepting ethical responsibility. James characterizes Clifford's position as follows: "Better risk loss of truth than chance of error" (James 1956: 26). In contrast, I can only act ethically where I am exposed to the risks of error and failure. Otherwise, I would not be acting at all, but merely operating or carrying out a calculus. Against the backdrop of these thoughts, in his decidedly moral philosophical writings James assumes a post-conventional position, that is, we are not acting ethically if we simply subject our actions to rules, but only if we also come to realize that no rule can ever claim that it was the single adequate rule for the case in question: "The highest ethical life [...] consist at all times in the breaking of rules which have grown too narrow for the actual case" (James 1956: 209). It is not the task of ethics to come up with universal solutions, but to strive for justice in every single and particular case: "For every real dilemma is in literal strictness a unique situation" (James 1956: 209). Ethics thus turns into an endless and always self-referential task. At the beginning of his essay The Moral Philosopher and Moral Life, James points out that the definite shape of ethics can only be determined: "until the last man has had his experience and said his say" (James 1956: 184).

With this plea for the moral significance of ignorance, James does not mean to imply that knowledge and rules should not play a role in ethical decision-making. As a philosopher with a high affinity for science, like Clifford, James rejects any resignation to wilful ignorance. What he does decline, however, is the idea that, when it comes to practice, it is possible to achieve exhaustive knowledge of it and that an entirely justified knowledge is indispensable as the foundation for an ethically acceptable action. With respect to knowledge and ignorance, we find ourselves in an aporetic situation that Derrida explains as follows:

Saying that a responsible decision must be taken on the basis of knowledge seems to define the condition of possibility of responsibility (one can't make a responsible decision without science or conscience, without knowing what one is doing, for what reasons [...]), at the same time as it defines the condition of impossibility of this same responsibility (if decision-making is relegated to a knowledge that it is content to follow [...], then it is no more a responsible decision. (Derrida 1995a, 24)

This aporia cannot be resolved on a theoretical level - at best we can live it.

In his Ethics, published in 1908 in co-authorship with James Hayden Tufts and republished in 1932 in a heavily revised second edition, Dewey takes up James's agenda of a pragmatist ethics. But the naturalistic foundation for his ethics had already been established in 1896 with his essay The Reflex Arc Concept in Psychology (EW 5: 96-109), where he develops a theory of experience that claims validity for theoretical and practical experiences alike. This theory of experience unfolds in five steps (see Edel, Flower 1985: $\mathrm{X})$ : (1) the initial point of every experience is a life crisis or a situation that has became problematic and stimulates a process of inquiry; (2) this process of inquiry is a practical process, that is to say, a practice; (3) the process is at the same time reconstructive and experimental, it involves innovations (new beginnings) concerning the assessment of the situation and the search for solutions respectively; (4) the process (or practice) has a temporal structure and reflects upon its own temporality, and (5) the whole process must be conceived in a holistic way. Intentions, experiences, consequences of actions, as well as the self, are dimensions of the process or practice rather than self-contained elements. 

ethics is a departure from universal moral principles. The project of a "moral inquiry" seeks for specific answers to specific problems in specific contexts, rather than for what is good for everyone at all times. For Dewey, ethics does not establish general forms or patterns of conduct, but understands itself as a reflection. It does not see itself as referring to reason as an underlying principle, but to intelligence as a situational and, above all, a practical capacity. In the preface to the 1932 edition of Ethics, the editors accurately remark that "reason is low keyed" (Edel \& Flower 1985: XXIII) in Dewey's ethics, and, furthermore, that "the work of analysis has to be done in each case" (Edel \& Flower 1985: XXXIII). It cannot resort to any pre-existing or extra-practical orientations. What counts as an ethically adequate answer to a situation - Dewey herein follows James - has to be explored afresh in every new situation, while sticking to eternal values and norms brings about a tendency to not even realize the newness of a situation. For Dewey, a practice that is different every time and based upon beginnings is the source of any ethical orientation. It precedes us, but does not determine us and is not itself externally determined. Practice confronts us with an ever-changing 'ought-to' that can be conceived as given, but at the same time cannot be characterized in terms of propositional knowledge.

Just as practice mediates between is and ought, it also mediates between society and the individual. In his 1920 essay Reconstruction in Philosophy, Dewey writes:

Just as "individual" is not one thing, but is a blanket term for the immense variety of specific reactions, habits, dispositions and powers of human nature that are evoked, and confirmed under the influences of associated life, so with the term "social." Society is one word, but infinitely many things. (MW 12:194)

31 Based upon the pragmatist notion of practice, the individual as well as the social appear as empty signifiers or abstractions, which is why ethics according to Dewey does not have to choose between defending the demands of the individual or the demands of society as such. In times of social petrification and conformism, ethics defends the perspective of the individual. Whereas in times of constant upheaval and individualism, ethics is more likely to defend the demands of the community. But in the end both sides are no more than abstractions of one and the same practice. The same goes for other antagonistic conceptual dualisms within the tradition of ethics, as, for example, motives of actions (as the pivotal point of deontological principle ethics), and consequences of actions (upon which utilitarianism bases ethical actions). For Dewey, both terms are always already "embodied in action" (LW 7: 173): will is nothing more than a tendency towards certain consequences, while consequence is nothing more than the realization of a will.

Ethics in general is affected by this anti-dualism in that Dewey conceives it as a practice rather than as a moral theory:

No fundamental difference exists between systematic moral theory [...] and the reflection an individual engages in when he attempts to find general principles which shall direct and justify his conduct. (LW 7: 163)

Accordingly, moral reflection for Dewey offers no theory or meta-language of practice, but is just another shape of practice itself. It can never definitely resolve a crisis, never definitely judge an action or person by means of a norm. The primal scene of ethics for Dewey does not consist in the conflict between a norm and a temptation to violate it, but in a conflict between equal norms. Ethics 
[...] does not offer a table of commandments in a catechism in which answers are as definite as are the questions which are asked. It can render personal choice more intelligent, but it cannot take the place of personal decisions, which must be made in every case of moral perplexity. (LW 7: 166) recognition and respect from Cavell's perspective is not a continuous transition: "Acknowledgment goes beyond knowledge" (Cavell 1976: 257). He asks whether respect requires knowledge of the Other or if, rather, it does not require a suspension of knowledge in order to respect the Other precisely in his or her alterity. If respect is reduced to a recognition of attributes and capacities, it runs the risk of extending social exclusions. Thus Cavell criticizes even the humanistic demand to respect those who are excluded or have no part: The intention of humanism

[...] is to acknowledge the outcast as a human being; but his effect is to treat a human being as an outcast, as if the condition of outcastness defined a social role, a kind of sub-profession, suited for a certain kind of human being. So it is apt to perpetuate the guilt it means to assuage. (Cavell 1999: 437) 
to accept my exposure in the case of others seems to imply an acceptance of the possibility that my knowledge of others may be overthrown, even that it ought to be. (Cavell 1999: 439) point of view particularly concerns the relation of ethical action and compliance with rules. From his perspective, modernity tends to define ethics as ethical expertise, as knowledge of rules. With Wittgenstein, he points out a kind of indeterminateness between a rule and the practice that is to be ruled. In his thoughts on the ability to teach mathematics, the competent continuation of number series, the later Wittgenstein points out that it is possible to specify more than one rule for every number series. This in turn means that every series can be adequately continued in more than one way. If the maths teacher acts on the assumption of a single commonly used rule that may even appear to be the only possible rule, he runs the risk of excluding a student who continues the series differently than expected. From this perspective, I become "morally competent" (Cavell 1999: 267) only if I am able to acknowledge the relevance of the doubts others might have concerning my rule.

41

In this context, Cavell strives for a "moralization of moral theory" (Cavell 1999: 269): "Morality must leave itself open to repudiation" (Cavell 1999: 269). In practice, this means that the questions as to "what will be making it a moral issue, what kinds of reasons, entered in what way, to what effect, will be moral reasons" (Cavell 1999: 289) and who counts as a moral agent or patient in which context, are considered moral questions. It has been pointed out, especially by the modern critique of morality as represented, for example, by Marx, Nietzsche, and Freud, that it is crucial to integrate this point consistently into the moral discourse. In a similar vein, Derrida, who has taken up this moral critical line of thought, considers the key questions of ethics to be: "What is the ethicity of ethics? The morality of moral? What is responsibility?" For him, those questions to a certain extent must remain:

unanswered, at any rate without a general and rule-governed response, without a response other than that which is linked specifically each time, to the occurrence of a decision without rules and without will in the course of a new test of the undecidable. (Derrida 1995b: 16ff.)

Taking up a Searlean distinction, it could be said that, for Cavell, rules in moral contexts play an at best regulative, but never a constitutive role:

No rule or principle could function in a moral context the way regulatory or defining rules function in games. It is as essential to the form of life called morality that rules so conceived be absent as it is essential to the form of life we call playing a game that they be present. (Cavell 1999: 307)

When it comes to ethics, the reference to rules is always belated, as, rather than explaining what we ought to do, these rules can only be understood as a function of an 'ought': "For rules are themselves binding only subject to our commitment" (Cavell 1999: 307). This 'ought' contains an indeterminateness: '“Ought,' unlike 'must,' implies that there is an alternative course you may take, may take responsibility for" (Cavell 1999: 498). In contrast, the rules of a game imply a must. They exclude alternatives. Within the game, we become inhabitants of a realm of necessity, whereas in morality we are free to relate to the laws this way or another way. In Robert Brandom's words:

The rules do not immediately compel us, as natural ones do. Their compulsion is rather mediated by our attitude towards those rules. What makes us act as we do is not the rule or norm itself but our acknowledgement of it. (Brandom 1994: 31)

European Journal of Pragmatism and American Philosophy, VII-1 | 2015 

Cavell, moral arguments: "may always break down" (Cavell 1999: 255). Indeed, it is precisely this possibility (which is at the same time the possibility of future) that defines them as moral arguments. The fact "that moral disagreements are not to be settled the way disagreements about logical or factual matters are" (Cavell 1999: 260) does not mean that, from Cavell's perspective, moral questions are more irrational than factual questions. Rather, their precarious state is due to a certain self-reflectiveness of morality. A moral situation for Cavell is not one of blind rule application, but, as for James, a postconventional and creative one in which we remain in doubt over the rule to be applied, as well as the interpretation of the case to be ruled:

Apparently, what the 'case' in question is forms part of the content of the moral argument itself. Actions, unlike envelopes and goldfinches, do not come named for assessment, nor, like apples, ripe for grading. The most serious sense, to my mind, in which Kant's moral theory is 'formalistic' comes not from his having said that actions motivated only in certain ways are moral actions but in his having found too little difficulty in saying what 'the' maxim of an action is in terms of which his test of its morality, the Categorical Imperative, is to be applied. (Cavell 1999: 265)

Cavell accentuates the moral relevance of the question of how an action can be described and recognized as morally significant. Intellectualist ethics ignore the fact "that there is this problem about how an action is to be described" (Cavell 1999: 265), that whatever description of an action we come up with, the motives of action and another's person's guiding rules o run the risk of what Adorno could call: "false projection."

To sum up, James, Dewey, and Cavell remain loyal to the Kantian agenda of pointing out limits of knowledge in order to concede to ethics a realm that has a validity of its own. Based on pragmatism, we should strive for as much knowledge as possible, all the more so in situations in which ethical decisions are at stake, but at the same time reflect upon the limits of what we can possibly know, that is, on the things we do not yet know, but should know in order to make responsible decisions here and now, and above all, on the things we might never be capable of knowing as a matter of principle. From this perspective, ethics is not a form of knowledge, but a way of critically and creatively dealing with knowledge that must never run out.

\section{BIBLIOGRAPHY}

BRANDOM R., (1994), Making it explicit, Cambridge/MA, Harvard University Press.

CAVell S., (1976), Must we Mean what we Say?, Cambridge, Cambridge University Press.

CAVELl S., (1999), The Claim of Reason (New Edition), New York, Oxford University Press.

CLIFFORD W. K., (1999), Ethics of Belief and Other Essays, New York, Prometheus Books.

DERRIDA J., (1995a), The Gift of Death, Chicago, University of Chicago Press.

DERRIDA J., (1995b), On the Name, Stanford, Stanford University Press.

European Journal of Pragmatism and American Philosophy, VII-1 | 2015 
DEWEY J., EW, (1969-1972), The Early Works of John Dewey, 1882-1898, ed. by J. A. Boydston, Southern Illinois University Press, Carbondale and Edwardsville.

DEWEY J., MW, (1976-1983), The Middle Works of J. Dewey, 1899-1924, ed. by J. A. Boydston, Southern Illinois University Press, Carbondale and Edwardsville.

DEWEY J., LW, (1981-1990), The Later Works of J. Dewey, 1925-1953, ed. by J. A. Boydston, Southern Illinois University Press, Carbondale and Edwardsville, 1981-1990.

EDEL A. \& E. FLOWER, (1985), “Introduction” to John Dewey, Ethics, in LW7: vii-xxxv.

GEORGES K. E., (1910), Ausführliches lateinisch-deutsches Handwörterbuch, Leipzig, Hahnsche Buchhandlung.

HARDY J., (2010), “Is Virtue Knowledge? Socratic Intellectualism reconsidered," in Proceedings of the Boston Area Colloquium in Ancient Philosophy, 2010, 149-191.

HORSTER D., (2012), “Introduction” to Horster ed., Texte zur Ethik, 2012, Stuttgart, Reclam.

JAmes W., (1956), The Will to Believe and other Essays in Popular Philosophy, New York, Dover Publications.

KANT I., (1991), The Metaphysics of Morals, trans. Mary J. Gregor, Cambridge, Cambridge University Press.

KANT I., (2002a), Groundwork for the Metaphysics of Morals, edited and translated by Allen W. Wood, New Haven and London, Yale University Press.

KANT I., (2002b), Critique of Practical Reason, trans. Werner S. Pluhar, Indianapolis/ Cambridge, Hackett.

LACLAU E., (2000) “Identity and Hegemony," in J. Butler, E. Laclau \& S.Žižek , Contingency, Hegemony, Universality. Contemporary Dialogues on the Left, London/New York, Verso, 2000, 44-89.

LACLAU E., (2002), "Ethics, Politics and Radical Democracy - A Response to Simon Critchley," in Culture Machine, vol. 4 (2002). Electronic version: [culturemachine.net/index.php/cm/article/ viewArticle/268/253] (20.06.2013).

PEIRCE C. S., (1931), Collected Papers, vol. 1, ed. Charles Hartshorne/Paul Weiss, Cambridge/Mass., Harvard University Press.

PLATO, (1997), Complete Works, edited by John M. Cooper, Indianapolis/Cambridge, Hackett.

SNELL B., (1955), Die Entdeckung des Geistes, Göttingen, Vandenhoeck \& Ruprecht.

\section{NOTES}

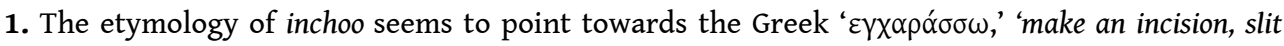
something open' (compare Georges 1910, vol. 2, 145). 


\section{ABSTRACTS}

Starting from a pragmatist point of view the paper dismisses the argument that ethical conduct is always based on knowledge of justifying and applying rules. In a first section I show that Plato and Kant already claimed that the originality of the ethical can't be represented as either propositional knowledge or a norm, but is instead given to us in a way that is never fully available for our rational grasp. In a second section, I will address the ethical conclusions James and Dewey draw from the fact that ethical demands can't be translated into forms of knowledge. In a third section, I conclude with an argument for the originality of the ethical based on the thoughts of Stanley Cavell, stating that it is always something more than a mere competence in the sense of a knowledge of rules.

\section{AUTHORS}

\section{ANDREAS HETZEL}

Otto von Guericke Universität, Magdeburg

hetzel[at]phil.tu-darmstadt.de 